\title{
HUBUNGAN PENGETAHUAN IBU TENTANG JAJANAN DENGAN PEMILIHAN JAJANAN UNTUK ANAK USIA TODLER DI RW 13 KELURAHAN JATISAMPURNA BEKASI TAHU 2012
}

\author{
Lina Ayu Marcelina ${ }^{1}$, Herlina $^{2}$, Maulina $^{3}$, Evin Novianti ${ }^{4}$ \\ Fakultas Ilmu Ilmu Kesehatan Universitas Pembangunan Nasional "Veteran" \\ Jakarta,Indonesia \\ Email : celi_mutan@yahoo.co.id
}

\begin{abstract}
Abstrak
Pada usia todler, anak belum memiliki kemampuan untuk menentukan jajanan mana yang baik untuk mereka sehingga peranan ibu sangat dibutuhkan dalam hal ini. Tujuan penelitian ini adalah untuk mengidentifikasi hubungan pengetahuan ibu tentang jajanan dengan pemilihan jajanan untuk anak usia todler. Sampel total sampling sebanyak 42 ibu. Makanan jajanan merupakan makanan dan minuman yang dijual oleh pedagang dan dapat langsung dimakan tanpa pengolahan lebih lanjut. Pemilihan jajanan ibu dibagi menjadi jajanan sehat dan tidak sehat dan untuk mengidentifikasi digunakan kuisioner yang diisi oleh responden. Hasil penelitian sebagian besar responden berusia $>32$ tahun, memiliki pendidikan menengah ke atas, tidak bekerja, membeli jajanan di minimarket, memiliki pengetahuan tinggi dan memilih jajanan sehat. Uji statistik menunjukkan tidak terdapat hubungan bermakna antara usia ibu dengan pemilihan jajanan (P 0.209dan OR 0.338), terdapat hubungan antara pendidikan ibu (P 0.020 dan OR 7.000), pekerjaan ibu (P 0.031 dan OR 5.909) dan pengetahuan ibu tentang jajanan (P 0.017 dan OR 6.000) dengan pemilihan jajanan. Orang tua diharapkan lebih aktif dalam mencari informasi makanan jajanan yang sehat sehingga bisa diterapkan saat memilih jajanan untuk anak.
\end{abstract}

Kata kunci : pengetahuan ibu, jajanan, pemilihan jajanan 


\section{Latar Belakang}

Makanan usia todler (1-3 tahun) banyak tergantung pada orang tua atau pengasuhnya (Potter dan Perry,2005). Todler yang memiliki keinginan untuk memakan satu makanan secara berulang mendorong orang tua untuk menyediakan berbagai macam makanan bergizi dan makanan ringan di antara waktu makan.

Hal ini diperkuat dengan pernyataan Sothern dan Gordon (2003 dalam Mandleco dan Potts,2007) dimana selain makanan utama, makanan ringan juga disediakan di antara waktu makan todler.

Makanan jajanan yang dijual oleh pedagang kaki lima menurut FAO didefinisikan sebagai makanan atau minuman yang dipersiapkan dan atau dijual oleh pedagang kaki lima di jalanan dan di tempat keramaian umum lain yang langsung dimakan tanpa pengolahan atau persiapan lebih lanjut. Namun, laporan Food Watch BPOM memaparkan bahwa jajanan sering tidak memenuhi syarat (TMS) dan tidak menyehatkan karena penggunaan bahan tambahan makanan (BTP) yang melebihi batas, penyalahgunaan bahan berbahaya dan terdapatnya cemaran mikroba. Makanan jajanan yang tidak sehat dapat menimbulkan efek bagi kesehatan. Bahaya makanan jajanan tersebut dapat muncul dalam jangka pendek seperti keracunan, mual, muntah dan diare.

Adapun bahaya jangka panjang jajanan tidak menyehatkan terutama terjadi apabila ditambahkan bahan yang bersifat pemicu kanker (karsinogenik). Apabila tidak memperhatikan dengan seksama ciri jajanan tersebut maka dampak jangka pendek dan panjang dapat terjadi pada anak. Hasil penelitian Pitaloka (2010) menegaskan bahwa terdapat hubungan bermakna antara jajanan dengan Infeksi Saluran Pernafasan Atas (ISPA).

Pengetahuan ibu sangat diperlukan dalam pemilihan makanan yang tepat dan baik (Suhardjo,2003). Semakin bertambah pengetahuan ibu maka seorang ibu akan semakin mengerti jenis dan jumlah makanan untuk dikonsumsi termasuk memilih jajanan yang sehat untuk buah hatinya.

Hasil penelitian Purtiantini (2010) menunjukkan bahwa tidak ada hubungan antara pengetahuan anak mengenai pemilihan makanan jajanan dengan perilaku memilih makanan. Juliana dkk (2010) dalam penelitian mereka juga menegaskan bahwa terdapat hubungan bermakna antara tingkat pengetahuan ibu tentang gizi seimbang dengan pemilihan jajanan pada anak.

Anak usia todler masih tergantung orang tua dalam memilih makanan termasuk jajanan. Bahaya yang ditimbulkan dari jajanan tidak sehat seperti keracunan bahkan kanker sangat mengkhawatirkan orang tua. Pengetahuan ibu tentang jajanan sangat diperlukan agar pemilihan jajanan untuk anak todler menjadi tepat.

\section{Tujuan Penelitian}

Tujuan penelitian ini untuk mengetahui hubungan pengetahuan ibu tentang jajanan dengan pemilihan jajanan pada anak usia todler di RW 13, Kelurahan Jatisampurna Bekasi tahun 2012.

\section{Metode Penelitian}

Penelitian ini merupakan penelitian deskriptif kuantitatif dengan menggunakan desain penelitian cross sectional tentang hubungan pengetahuan ibu tentang jajanan dengan pemilihan jajanan untuk anak usia todler di RW 13, Kelurahan Jatisampurna Bekasi yang dilakukan bulan Juni-Juli 2012.

Teknik pengambilan sampel adalah total sampling. Penelitian ini dilakukan untuk mengetahui hubungan pengetahuan ibu tentang jajanan dengan pemilihan jajanan untuk anak. Responden berjumlah 38 ibu yang memiliki anak usia 1-3 tahun. Analisis statistik yang digunakan yaitu univariat dan bivariate dengan analisis independen dan dependen Chi square.

\section{Hasil dan Pembahasan \\ a. Gambaran Karakteristik Ibu}

Penelitian dilakukan di RW 13 Kelurahan Jatisampurna Bekasi terhadap 38 responden yakni ibu yang memiliki anak usia 1-3 tahun yang diminta mengisi kuisioner, hasil analisisnya adalah sebagai berikut :Hasil analisis karakteristik ibu menunjukkan dari total 38 orang ibu, sebagian besar berusia $>30$ tahun, berpendidikan tinggi sebesar 
92.1\%, dan pekerjaan ibu sebagian besar sebagai ibu rumah tangga.

Tabel 1. Analisis Univariat Karakteristik Ibu Di RW 13 Kelurahan Jatisampurna Bekasi Tahun 2012

\begin{tabular}{|c|c|c|c|}
\hline Variabel & Hasil Ukur & $\mathrm{f}$ & $\%$ \\
\hline \multirow{2}{*}{ Umur } & $\leq 32$ thn & 15 & 35.7 \\
\cline { 2 - 4 } & $>32$ thn & 27 & 64.3 \\
\hline & & 42 & 100 \\
\hline Pendidikan & Dasar & 12 & 28.6 \\
\cline { 2 - 4 } & $\begin{array}{c}\text { Menengah } \\
\text { Atas }\end{array}$ & 30 & 71.4 \\
\hline & IRT & 42 & 100 \\
\hline Pekerjaan & Bekerja & 16 & 61.9 \\
\cline { 2 - 4 } & & 42 & 100 \\
\hline
\end{tabular}

Data tersebut memperlihatkan bahwa mayoritas responden berusia dewasa tengah ( $>32$ tahun), jika merujuk pada teori perkembangan Levinson di atas bahwa masa dewasa tengah adalah fase "masa tenang" dan "masa keberhasilan" dimana telah mencapai keberhasilan dalam pencapaian pribadi sehingga kini mereka menemukan kesenangan istimewa dalam membantu anaknya maupun orang lain agar menjadi produktif dan bertanggung jawab (Potter\&Perry,2005).

Dari teori di atas dapat disimpulkan bahwa sebagian besar responden di RW 13 Kelurahan Jatisampurna Bekasi yang berusia dewasa tengah merupakan komunitas membantu orang lain dalam mengarahkan agar dapat memilih makanan jajanan yang sehat.

Menurut Notoatmodjo (2003) pendidikan adalah suatu kegiatan atau proses pembelajaran untuk mengembangkan atau meningkatkan kemampuan tertentu sehingga sasaran pendidikan itu dapat berdiri sendiri. Tingkat pendidikan turut pula menentukan mudah tidaknya seseorang menyerap dan memahami pengetahuan yang mereka peroleh, pada umumnya semakin tinggi pendidikan seseorang semakin baik pula pengetahuannya. Dari hasil yang diperoleh sebagian besar ibu berpendidikan tinggi maka pendidikan ibu berperan dalam menentukan seberapa tinggi pengetahuan ibu tentang jajanan.

Berdasarkan hasil penelitian pekerjaan sebagian besar ibu adalah ibu rumah tangga.
Data Badan Pusat Statistik yaitu Survei Sosial Ekonomi Nasional 2004 didapatkan sebagian besar ibu usia kurang dari 40 tahun yang mempunyai anak, hanya mengurus rumah tangga saja $(63,3 \%)$ dan yang bekerja hanya $29,6 \%$ saja.

Hasil penelitian ini sejalan dengan penelitian yang dilakukan oleh Nur'aeni (2008) yaitu hasil distribusi frekuensi ibu yang tidak bekerja lebih besar daripada ibu yang bekerja yaitu sebanyak $70.1 \%$.

\section{b. Gambaran Jajanan}

Berdasarkan tempat membeli jajanan di RW 13 Kelurahan Jatisampurna, diperoleh gambaran bahwa dari 42 responden, 14 orang (33.3\%) membeli di warung dan 28 orang $(66.7 \%)$ membeli di minimarket, tidak ada responden yang membeli jajanan di pasar dan pedagang keliling (0\%). Dari tabel tersebut sebagian besar responden membeli jajanan untuk anaknya di minimarket.

Tabel 2. Analisis Univariat Gambaran Jajanan Di RW 13 Kelurahan Jatisampurna Bekasi Tahun 2012

\begin{tabular}{|c|c|c|}
\hline Tempat & frekuensi & $\%$ \\
\hline Warung & 14 & 33.3 \\
\hline Minimarket & 28 & 66.7 \\
\hline Pasar & - & - \\
\hline $\begin{array}{c}\text { Pedagang } \\
\text { keliling }\end{array}$ & - & - \\
\hline Jumlah & 42 & 100 \\
\hline
\end{tabular}

Salah satu kiat memilih makanan jajanan yang baik adalah memilih pangan yang dijual di tempat bersih dan terlindung dari : matahari, debu, hujan, angin dan asap kendaraan bermotor serta pilih tempat yang bebas dari serangga dan sampah. Ciri lain mengenali jajanan sehat bisa dilihat dari lokasi jualan. Memilih tempat jajanan yang sehat bisa meminimalisir kemungkinan cemaran mikrobiologi pada makanan. Penting bagi orang tua (terutama ibu) untuk memperhatikan dimana tempat membeli jajanan untuk anak. Dari data yang diperoleh, sebagian besar ibu membeli jajanan di minimarket.

Dari berbagai teori di atas maka dapat disimpulkan bahwa cara memilih jajanan sehat adalah dengan melihat tempat membeli jajanan itu, diharapkan tempat 
tersebut dapat memenuhi syarat tempat membeli jajanan sehat yakni bebas dari debu, asap kendaraan dan matahari.

Tabel 3.Analisis Univariat Gambaran Pengetahuan Ibu Di RW 13 Kelurahan Jatisampurna Bekasi Tahun 2012

\begin{tabular}{|c|c|c|}
\hline Pengetahuan & frekuensi & $\%$ \\
\hline Rendah & 18 & 42.9 \\
\hline Tinggi & 24 & 57.1 \\
\hline Jumlah & 42 & 100 \\
\hline
\end{tabular}

Berdasarkan pengetahuan ibu di RW 13 Kelurahan Jatisampurna Bekasi, diperoleh gambaran bahwa dari 42 responden, 18 orang $(42.9 \%)$ memiliki pengetahuan rendah dan 24 orang $(57.1 \%)$ memiliki pengetahuan tinggi. Dari data tersebut sebagian besar responden memiliki pengetahuan tinggi. Hasil penelitian ini sejalan dengan penelitian yang dilakukan Juliana dkk. (2010) yakni ibu yang memiliki pengetahuan tinggi sebanyak $52 \%$ sedangkan yang memiliki pengetahuan rendah sebanyak $48 \%$. Hasil penelitian yang dilakukan di RW 13 Kelurahan Jatisampurna dapat kita simpulkan bahwa dengan mayoritas masyarakat yang memiliki pengetahuan tinggi tentang jajanan merupakan sumber daya positif yang dapat dimanfaatkan guna meningkatkan kualitas pemilihan jajanan sehat untuk anak usia todler.

Tabel 4.Analisis Univariat Gambaran Pemilihan Jajanan Di RW 13 Kelurahan Jatisampura Bekasi Tahun 2012

\begin{tabular}{|c|c|c|}
\hline Pemilihan & frekuensi & $\%$ \\
\hline $\begin{array}{c}\text { Jajanan Tidak } \\
\text { Sehat }\end{array}$ & 18 & 42.9 \\
\hline Jajanan Sehat & 24 & 57.1 \\
\hline Jumlah & 42 & 100 \\
\hline
\end{tabular}

Berdasarkan pemilihan jajanan di RW 13 Kelurahan Jatisampurna Bekasi Tahun 2012, diperoleh gambaran bahwa dari 42 responden, 17 orang (42.9\%) memilih jajanan tidak sehat dan 24 orang (57.1\%) memilih jajanan sehat. Dari tabel tersebut sebagian besar responden memilih jajanan sehat.

Hasil penelitian yang dilakukan di RW 13 Kelurahan Jatisampurna Bekasi dapat kita simpulkan bahwa dengan mayoritas ibu yang memilih jajanan sehat merupakan komunitas yang positif dalam upaya peningkatan motivasi khususnya para ibu agar memilih jajanan yang sehat untuk buah hatinya. Dikarenakan anak usia todler belum memiliki kemandirian untuk menentukan jajanan mana yang baik untuk dirinya maka peranan seorang ibu dalam memilih jajanan yang sangat dibutuhkan di sini.

\section{c. Analisis Bivariat}

Tabel 5. Hubungan Usia Ibu dengan Pemilihan Jajanan Untuk Anak Usia Todler Di RW 13 Kelurahan Jatisampurna Bekasi Tahun 2012

\begin{tabular}{|c|c|c|c|c|c|c|}
\hline \multirow{2}{*}{ Usia } & \multicolumn{3}{|c|}{ Pemilihan Jajanan } & \multicolumn{2}{c|}{ Jumlah } \\
\cline { 2 - 6 } & $\begin{array}{c}\text { Tidak } \\
\text { Sehat }\end{array}$ & \multicolumn{2}{c|}{ Sehat } & \multicolumn{2}{|c}{} \\
\cline { 2 - 7 } & $\mathrm{n}$ & $\%$ & $\mathrm{n}$ & $\%$ & $\mathrm{n}$ & $\%$ \\
\hline$\leq 32$ & 4 & 26.7 & 11 & 73.3 & 15 & 100 \\
\hline$>32$ & 14 & 51.9 & 13 & 48.1 & 27 & 100 \\
\hline Jml & 18 & 42.9 & 24 & 57.1 & 42 & 100 \\
\hline
\end{tabular}

Berdasarkan hasil analisis bivariat, diketahui dari 15 responden berusia dewasa awal, terdapat 11 orang $(73.3 \%)$ yang memilih jajanan sehat dan 4 orang $(26.7 \%)$ memilih jajanan tidak sehat. Sedangkan dari 27 responden berusia dewasa tengah, diketahui 14 orang $(51.9 \%)$ memilih jajanan tidak sehat dan 13 orang (49.1\%) memilih jajanan sehat.

P value dari hasil penelitian sebesar 0.209 , nilai $\mathrm{P}$ value ini lebih besar dari alpha (0.05) maka Ho diterima, artinya secara statistik tidak terdapat hubungan yang bermakna antara usia ibu dengan pemilihan jajanan untuk anak usia todler. Nilai Odds Ratio (95\% Confidence Interval : 0.086-1.330) sebesar 0.338 artinya ibu yang berusia dewasa awal berpeluang 0.338 kali memilih jajanan tidak sehat dibandingkan ibu yang berusia dewasa tengah.Dari hasil penelitian dan merujuk teori di atas maka dapat disimpulkan bahwa berapa pun usia ibu maka ibu dapat memilih jajanan sehat, dengan kata lain tidak ada hubungan antara usia ibu dengan kemampuan ibu dalam memilih jajanan sehat untuk anaknya.

Tabel 6. Hubungan Pendidikan Ibu dengan Pemilihan Jajanan Untuk Anak Usia Todler Di RW 13 Kelurahan Jatisampurna Bekasi Tahun 2012

\begin{tabular}{|l|l|l|l|}
\hline Pendidikan & \multicolumn{2}{|c|}{ Pemilihan Jajanan } & \multirow{2}{*}{ Jumlah } \\
\cline { 2 - 3 } & $\begin{array}{c}\text { Tidak } \\
\text { sehat }\end{array}$ & Sehat & \\
\hline
\end{tabular}




\begin{tabular}{|c|c|c|c|c|c|c|}
\hline & $\mathrm{n}$ & $\%$ & $\mathrm{n}$ & $\%$ & $\mathrm{n}$ & $\%$ \\
\hline Dasar & 9 & 75 & 3 & 25 & 12 & 100 \\
\hline $\begin{array}{c}\text { Menengah } \\
\text { Atas }\end{array}$ & 9 & 35 & 21 & 70 & 30 & 100 \\
\hline Jumlah & 18 & 42.9 & 24 & 57.1 & 42 & 100 \\
\hline
\end{tabular}

Berdasarkan hasil analisis bivariat, diketahui bahwa dari 12 responden yang berpendidikan dasar, terdapat 9 orang $(75 \%)$ yang memilih jajanan tidak sehat dan 3 orang $(25 \%)$ memilih jajanan sehat. Sedangkan dari 30 responden yang berpendidikan menengah, diketahui 21 orang $(70 \%)$ memilih jajanan sehat dan 9 orang $(30 \%)$ memilih jajanan tidak sehat.

$\mathrm{P}$ value dari hasil penelitian sebesar 0.020 , nilai $\mathrm{P}$ value ini lebih kecil dari alpha (0.05) maka Ho ditolak, artinya secara statistik terdapat hubungan yang bermakna antara pendidikan ibu dengan pemilihan jajanan untuk anak usia todler. Nilai Odds Ratio (95\% Confidence Interval : 1.528-32.076) sebesar 7.000 artinya ibu yang berpendidikan dasar berisiko 7.000 kali memilih jajanan tidak sehat dibandingkan ibu yang berpendidikan menengah ke atas.

Hasil penelitian ini didukung oleh Kristiyanto (2006) yang menyatakan bahwa terdapat hubungan bermakna antara pendidikan ibu dengan status gizi balita. Rahayu (1994) juga menegaskan bahwa ditemukan hubungan positif bermakna antara pendidikan ibu dengan status gizi anak balita.

Dari penelitian terdahulu dan pendapat para ahli di atas maka hasil penelitian ini dapat menegaskan kembali bahwa terdapat hubungan bermakna antara pendidikan ibu dengan pemilihan jajanan untuk anak.

Tabel 7. Hubungan Pekerjaan Ibu dengan Pemilihan Jajanan Untuk Anak Usia Todler Di RW 13 Kelurahan Jatisampurna Bekasi Tahun 2012

\begin{tabular}{|c|c|c|c|c|c|c|}
\hline \multirow[t]{3}{*}{ Pekerjaan } & \multicolumn{4}{|c|}{ Pemilihan Jajanan } & \multirow{2}{*}{\multicolumn{2}{|c|}{ Jumlah }} \\
\hline & \multicolumn{2}{|c|}{$\begin{array}{l}\text { Tidak } \\
\text { sehat }\end{array}$} & \multicolumn{2}{|c|}{ Sehat } & & \\
\hline & $\mathrm{n}$ & $\%$ & $\mathrm{n}$ & $\%$ & $\mathrm{n}$ & $\%$ \\
\hline IRT & 15 & 57.7 & 11 & 42.3 & 26 & 100 \\
\hline Bekerja & 3 & 18.8 & 13 & 81.2 & 16 & 100 \\
\hline Jumlah & 18 & 42.9 & 24 & 57.1 & 42 & 100 \\
\hline
\end{tabular}

Berdasarkan hasil analisis bivariat, diketahui bahwa dari 26 responden yang tidak bekerja, terdapat 15 orang $(57.7 \%)$ yang memilih jajanan tidak sehat dan 11 orang $(42.3 \%)$ memilih jajanan sehat. Sedangkan dari 16 responden yang bekerja, diketahui 13 orang $(81.2 \%)$ memilih jajanan sehat dan 3 orang (18.8\%) memilih jajanan tidak sehat.

$\mathrm{P}$ value dari hasil penelitian sebesar 0.031 , nilai $\mathrm{P}$ value ini lebih kecil dari alpha (0.05) maka Ho ditolak, artinya secara statistik terdapat hubungan yang bermakna antara pekerjaan ibu dengan pemilihan jajanan untuk anak usia todler. Nilai Odds Ratio (95\% Confidence Interval : 1.349-25.879) sebesar 5.909 artinya ibu yang tidak bekerja berisiko 5.909 kali memilih jajanan tidak sehat dibandingkan ibu yang bekerja.Hasil penelitian ini menunjukkan bahwa dari 16 responden yang bekerja, sebagian basar memilih jajanan sehat untuk anaknya. Hal ini berarti ibu yang bekerja memiliki peluang untuk mendapat lebih banyak info terkait jajanan sehat dan memperoleh support system untuk berperilaku memilih jajanan sehat.

Dengan demikian dapat disimpulkan bahwa pekerjaan ibu berhubungan dengan pemilihan jajanan ibu untuk anaknya.

Tabel 8. Hubungan Pengetahuan Ibu Tentang Jajanan dengan Pemilihan Jajanan Untuk Anak Usia Todler Di RW 13

Kelurahan Jatisampurna Bekasi Tahun 2012

\begin{tabular}{|c|c|c|c|c|c|c|}
\hline \multirow{2}{*}{ Pengetahuan } & \multicolumn{3}{|c|}{ Pemilihan Jajanan } & \multirow{2}{*}{ Jumlah } \\
\cline { 2 - 6 } & \multicolumn{2}{|c|}{$\begin{array}{c}\text { Tidak } \\
\text { sehat }\end{array}$} & \multicolumn{2}{|c|}{ Sehat } & \multicolumn{2}{|c}{} \\
\cline { 2 - 6 } & $\mathrm{n}$ & $\%$ & $\mathrm{n}$ & $\%$ & $\mathrm{n}$ & $\%$ \\
\hline Rendah & 12 & 66.7 & 6 & 33.3 & 18 & 100 \\
\hline Tinggi & 6 & 25 & 18 & 75 & 24 & 100 \\
\hline Jumlah & 18 & 42.9 & 24 & 57.1 & 42 & 100 \\
\hline
\end{tabular}

Berdasarkan hasil analisis bivariat, diketahui bahwa dari 18 responden yang memiliki pengetahuan rendah, diketahui 12 orang (66.7\%) memilih jajanan tidak sehat dan 6 orang $(33.3 \%)$ memilih jajanan sehat. Sedangkan dari 24 responden yang memiliki pengetahuan tinggi, diketahui 18 orang (75\%) memilih jajanan sehat dan 6 orang (25\%) memilih jajanan tidak sehat.

$\mathrm{P}$ value dari hasil penelitian sebesar 0.017 , nilai $P$ value ini lebih kecil dari alpha (0.05) maka Ho ditolak, artinya secara statistik terdapat hubungan yang bermakna antara pengetahuan ibu tentang jajanan dengan pemilihan jajanan untuk anak usia todler. Nilai Odds Ratio (95\% Confidence Interval : 1.560-23.072) sebesar 6.000 artinya ibu yang memiliki pengetahuan rendah berisiko 6.000 kali memilih jajanan tidak sehat dibandingkan ibu yang memiliki pengetahuan tinggi. 
Hasil penelitian ini sejalan dengan penelitian yang telah dilakukan oleh Juliana dkk. (2010) yakni didapatkan hasil ada hubungan yang bermakna antara tingkat pengetahuan ibu tentang gizi seimbang dengan pemilihan jajanan pada anak usia sekolah dimana hasil uji statistik yaitu $\mathrm{P}=0.001$. Hasil penelitian ini juga sejalan dengan pendapat Soediotama (2004), semakin banyak pengetahuan gizinya, lebih banyak mempertimbangkan secara rasional dan pengetahuan tentang nilai gizi makanan tersebut dalam memilihkan makanan jajanan untuk anaknya.

Dari sebagian besar responden yang memiliki pengetahuan tinggi tentang jajanan, sebagian besar responden memilih jajanan sehat untuk anaknya. Hasil ini sejalan dengan pendapat Suhardjo (2003) yakni pengetahuan ibu tentang jajanan merupakan salah satu faktor yang menentukan pemilihan makanan jajanan dan semakin bertambah pengetahuan ibu maka seorang ibu akan semakin mengerti jenis dan jumlah makanan untuk dikonsumsi seluruh anggota keluarganya termasuk pada anak.

Dari berbagai faktor di atas dapat disimpulkan bahwa semakin tinggi pengetahuan ibu tentang jajanan memiliki kecenderungan akan memilih jajanan yang sehat. Sehingga hasil penelitian ini mendukung penelitian sebelumnya yang dilakukan oleh Juliana dkk. (2010) dan menegaskan pendapat yang dikemukakan oleh Soediotama (2004). Dengan demikian pengetahuan yang tinggi tentang jajanan perlu ditingkatkan agar menjadi pedoman dalam memilih jajanan yang sehat untuk anak

1. Gambaran karakteristik responden di RW 13 Kelurahan Jatisampurna Bekasi, sebagian besar responden (64.3\%) berusia dewasa tengah ( $>32$ tahun), $71.4 \%$ pendidikan ibu adalah menengah ke atas, dan $61.9 \%$ pekerjaan ibu adalah sebagai ibu rumah tangga.

2. Gambaran jajanan di RW 13 Kelurahan Jatisampurna Bekasi, sebagian besar responden $(66.7 \%)$ membeli jajanan untuk anaknya di minimarket.

3. Gambaran pengetahuan responden di RW 13 Kelurahan Jatisampurna Bekasi, sebagian besar responden (57.1\%) memiliki pengetahuan tinggi tentang jajanan.

4. Gambaran pemilihan jajanan di RW 13 Kelurahan Jatisampurna Bekasi, sebagian besar responden (57.1\%) memilih jajanan sehat untuk anaknya

5. Tidak terdapat hubungan bermakna antara usia ibu dengan pemilihan jajanan di RW 13 Kelurahan Bekasi, dengan P 0.209 dan nilai OR 0.338.

6. Terdapat hubungan bermakna antara pendidikan ibu dengan pemilihan jajanan di RW 13 Kelurahan Jatisampurna Bekasi, dengan P 0.020 dan nilai OR 7.000 .

7. Terdapat hubungan bermakna antara pekerjaan ibu dengan pemilihan jajanan di RW 13 Kelurahan Jatisampurna Bekasi, dengan P 0.031 dan nilai OR 5.909 .

8. Terdapat hubungan antara pengetahuan ibu tentang jajanan dengan pemilihan jajanan di RW 13 Kelurahan Jatisampurna Bekasi, dengan P 0.017 dan nilai OR 6.000.

Bagi BPOM diharapkan meningkatkan pengawasan terhadap peredaran makanan jajanan terutama jajanan yang tidak memenuhi syarat. Pengawasan dilakukan tidak hanya di kota besar melainkan sampai ke pelosok dan dilakukan secara berkala. Sehingga dapat memutus rantai penjualan makanan jajanan berbahaya bagi anak dan mencegah timbulnya korban akibat jajanan yang tidak memenuhi syarat.

Bagi tenaga kesehatan di masyarakat diharapkan perlu ditingkatkan lagi dalam melakukan usaha dengan memberikan informasi melalui penyuluhan untuk meningkatkan pengetahuan tentang jajanan anak, memberikan contoh jenis-jenis makanan jajanan yang sehat dan cara memilih jajanan yang sehat untuk anak usia toddler serta melakukan sosialisasi.

Diharapkan pada orang tua untuk lebih aktif dalam mencari informasi tentang makanan jajanan yang sehat sehingga bisa diterapkan saat mempertimbangkan dalam memilih jajanan untuk anak dan waspada saat membeli jajanan tersebut.

\section{Daftar Pustaka}

Aini.2010.Hubungan Asupan Makanan Anak Usia 0-2 Tahun Terhadap Perkembangan Motorik Anak Usia 2 Tahun Di Puskesmas Kasihan 1 Kab. Bantul Yogyakarta.Jurnal FK UMY.

Ali,Muhammad.2002.Pengetahuan, Sikap dan Perilaku Ibu Bekerja dan Tidak Bekerja 
Tentang

Imunisasi,Medan, http://library.usu.ac.id/modules.php., diakses 7 Juli 2012

Anggraini.2008.Hubungan Tingkat Pengetahuan Ibu Tentang Makanan Bergizi Dengan Status Gizi Balita Usia 1-3 tahun Di Desa Lencoh Wilayah Kerja Puskesmas Selo Boyolali.Skripsi Universitas Muhamadiyah,Surakarta.

Arikunto,Suharsimi.2005.Manajemen Penelitian.Jakarta:Rineka Cipta.

Aziz,RU.2009.Jangan Biarkan Anak Kita Bereaksi Menarik Diri.Solo:Tiga Serangkai.

Badan Pengawas Obat dan Makanan.2006.Jajanan Anak Sekolah, http://www.pom.go.id diakses tanggal 21 Maret 2012

2007.Food Watch,Sistem Keamanan Pangan Terpadu Vol.1 BPOM dengan WHO, http://www.pom.go.id, diakses 21 Maret 2012

Badan Pusat Statistik.2004.Survei Sosial Ekonomi Nasional, http://www.bps.go.id, diakses tanggal 7 Juli 2012

Dharma,Kelana Kusuma.2011.Metode Penelitian Keperawatan.Jakarta :Trans Info Media.

Direktorat Surveilan dan Penyuluhan Keamanan Pangan Deputi III Badan POM RI..2006.Bahaya Keamanan Pangan, http://www.pom.go.id/surv/events/Bahay a_KP.pdf, diakses 13 Maret 2012

FAO.1997.Street Foods (FAO food and nutrition paper)- Alimentation de rue (Etude FAO elimentation et nutrition)Ahmentos que se venden en lavia publica (Estudio FAO alimentaciony nutricion, Report of an FAO Technical Meeting On Street Food.India-Roma.

Februhartanty,J,\& Iswaranti,D.N.2004.Amankah Makanan Jajanan Anak Sekolah di Indonesia?, http://www.gizi.net.com. , diakses tanggal 13 Maret 2012

Hardinsyah.2012.Kekurangan Zat Gizi Mikro Hambat Pertumbuhan Anak, http://antaranews.co.id, diakses tanggal 6 Agustus 2012

Harry,Wied.1996.Gizi

Keluarga. Jakarta:Penebar Swadaya.
Hartanto.2006.Keluarga Berencana dan Kontrasepsi.Jakarta:Pustaka Sinar Harapan.

Hidayat,Aziz Alimul.2007.Metode Penelitian Keperawatan dan Teknik Analisa Data.Jakarta:Salemba Medika.

http://www.bps.go.id, diakses tanggal 15 Mei 2012

http://www.dikti.go.id/uu-no-20-tahun-2003, diakses tanggal 21 Maret 2012

http://www.kamusbahasaindonesia.org, diakses tanggal 7 Juli 2012

Juliana,Nisa,Maemunah,Juliani.2010.Hubungan Pengetahuan Ibu Tentang Gizi Seimbang Dengan Pemilihan Jajanan Pada Anak Usia Sekolah di RW 07 Kelurahan Tebet Kecamatan Manggarai,Skripsi FIK UI,Depok.

Kristiyanto.2006.Hubungan Pendidikan Ibu, Pengetahuan Gizi, Pendapatan Keluarga Dan Konsumsi Kalori Dengan Status Gizi Balita Di Puskesmas Beji Kecamatan Junrejo Batu.Jurnal UM,Malang.

Ma'ruf, Hendri.2005.Pengertian Minimarket. http://elib.unikom.ac.id/files, diakses tanggal 21 Mei 2012

Menteri Kesehatan Republik Indonesia.2003.Keputusan Menteri Kesehatan Republik Indonesia Nomor 942/MENKES/SK/VII/2003,Pedoman Persyaratan Hygiene Sanitasi Makanan Jajanan, http://www.depkes.go.id, diakses tanggal 21 Mei 2012.

Mandleco,Barbara

L.,Potts, Nicki L.2007.Pediatric Nursing.Canada: Thomson.

Notoadmodjo,Soekidjo.2003.Ilmu Kesehatan Masyarakat.Jakarta:Rineka Cipta.

Nur'aeni.2008.Hubungan Asupan Energi dengan Status Gizi Baduta di Wilayah Kerja Puskesmas Depok Jaya Kota Depok Tahun 2008.Skripsi FKM UI,Depok.

Pemerintah Provinsi Jawa Barat.2007.Perubahan RPJM, www.jabarprov.go.id/root/rpjmd/Perubah anRPJMDBABII.doc, diakses 7 Juli 2012

Pitaloka,Golda.2010.Hubungan Jajanan Anak Sekolah (6-12 tahun) dengan ISPA di SDN 7 Depok Jaya Tahun 2010.Skripsi FIKES UPN,Jakarta. 
Potter \& Perry.2005.Buku Ajar Fundamental Keperawatan. Jakarta: EGC.

Proboningsih.2004.Perbedaan Perkembangan (Motorik Kasar, Motorik Halus, Bahasa, Kepribadian) Pada Anak Usia 12-18 Bulan Antara Status Gizi Kurang dan Normal.Digilib Unair, http://digilib.unair.ac.id, diakses tanggal 6 Agustus 2012.

Purtiantini.2010.Hubungan Pengetahuan Dan Sikap Mengenai Pemilihan Makanan Jajanan Dengan Perilaku Anak Memilih Makanan Di SDIT Muhammadiyah Al Kautsar Gumpang Kartasura,Skripsi FIG Jawa Tengah.

Rahayu.1994. Hubungan Antara Beberapa Karakteristik Ibu Dengan Status Gizi Anak Balita Studi Kasus Pada Anak Balita Umur 2-3 tahun Di Desa Sukorejo Kecamatan Wedi Kabupaten Klaten.Tesis,UNDIP,Jawa Tengah.

Rahmi \& Muis.2005.Kontribusi Makanan Jajanan Terhadap Tingkat Kecukupan Energi dan Protein Serta Status Gizi Anak SD Siliwangi.Semarang:Media Medika Muda

Riyanto,Agus.2011.Aplikasi Metodologi Penelitian Kesehatan.Yogyakarta:Nuha Medika.

Soediotama,A.D.2004.Ilmu Gizi.Jakarta:Bumi Aksara.

Soehardjo.2003.Perencanaan pangan dan Gizi.Jakarta:Bumi Aksara.

Soendjojo dkk.2003.Menstimulasi Anak Usia 01 tahun.Jakarta:PT Elexmedia Komputindo.

Soetjiningsih.2005.Tumbuh Anak.Jakarta:EGC.

Suherman.2000.Buku Saku Perkembangan Anak.Jakarta:EGC.

Supartini.2004.Buku Ajar Konsep Dasar Keperawatan Anak.Jakarta:EGC

Supriasa,Bakri,Fajar.2002.Penilaian Gizi.Jakarta:EGC

Suryanah.1996.Perkembangan Anak.Jakarta:EGC.

Tarwotjo.1998.Dasar-Dasar Kuliner.Jakarta:Gramedia Utama.
Widiasari,Kartika.2001.Hubungan Pengetahuan Ibu,Besar Uang Jajan dan Kebiasaan Jajan Dengan Pemilihan Jajanan Di SDN Kayu Putih 09 Pagi Pulogadung Jakarta Timur.Laporan Penelitian S1 tidak diterbitkan,Universitas Indonesia,Jakarta,Indonesia.

Widia Karya Nasional Pangan dan Gizi.2004.Ketahanan Pangan dan Gizi di Era Otonomi Daerah dan Globalisasi, www.wnpg.go.id, diakses tanggal21 Maret 2012

Wiekke.2007.Hubungan Status Gizi dengan Status Perkembangan Motorik Anak Usia 0-3 tahun (Batita) Di Kecamatan Kejayan Kabupaten Pasuruan.Jurnal UM,Malang.

Wuryaningsih.2010.Hubungan Status Gizi Dengan Perkembangan Kognitif Balita Usia 24-59 Bulan Di Posyandu Desa Gonilan Kecamatan Kartasura Kabupaten Sukoharjo.Skripsi FK UM,Surakarta. 